\title{
REVIEW
}

\section{Responses of coral reefs and reef organisms to sedimentation}

\author{
Caroline S. Rogers \\ Virgin Islands National Park, PO Box 710, St. John, USVI 00830
}

\begin{abstract}
Unprecedented development along tropical shorelines is causing severe degradation of coral reefs primarily from increases in sedimentation. Sediment particles smother reef organisms and reduce light available for photosynthesis. Excessive sedimentation can adversely affect the structure and function of the coral reef ecosystem by altering both physical and biological processes. Mean sediment rates and suspended sediment concentrations for reefs not subject to stresses from human activities are $<1$ to ca $10 \mathrm{mg} \mathrm{cm}^{-2} \mathrm{~d}^{-1}$ and $<10 \mathrm{mg} \mathrm{l}^{-1}$, respectively. Chronic rates and concentrations above these values are 'high'. Heavy sedimentation is associated with fewer coral species, less live coral, lower coral growth rates, greater abundance of branching forms, reduced coral recruitment, decreased calcification, decreased net productivity of corals, and slower rates of reef accretion. Coral species have different capabilities of clearing themselves of sediment particles or surviving lower light levels. Sediment rejection is a function of morphology, orientation, growth habit, and behavior; and of the amount and type of sediment. Coral growth rates are not simple indicators of sediment levels. Decline of tropical fisheries is partially attributable to deterioration of coral reefs, seagrass beds, and mangroves from sedimentation. Sedimentation can alter the complex interactions between fish and their reef habitat. For example, sedimentation can kill major reef-building corals, leading to eventual collapse of the reef framework. A decline in the amount of shelter the reef provides leads to reductions in both number of individuals and number of species of fish. Currently, we are unable to rigorously predict the responses of coral reefs and reef arganisms to excessive sedimentation from coastal development and other sources. Given information on the amount of sediment which will be introduced into the reef environment, the coral community composition, the depth of the reef, the percent coral cover, and the current patterns, we should be able to predict the consequences of a particular activity. Models of physical processes (e.g. sediment transport) must be complemented with better understanding of organism and ecosystem responses to sediment stress. Specifically, we need data on the threshold levels for reef organisms and for the reef ecosystem as a whole - the levels above which sedimentation has lethal effects for particular species and above which normal functioning of the reef ceases. Additional field studies on the responses of reef organisms to both terrigenous and calcium carbonate sediments are necessary. To effectively assess trends on coral reefs, e.g. changes in abundance and spatial arrangement of dominant benthic organisms, scientists must start using standardized monitoring methods. Long-term data sets are critical for tracking these complex ecosystems.
\end{abstract}

\section{INTRODUCTION}

Sedimentation from dredging and runoff constitutes one of the biggest potential sources of reef degradation from human activities in the Caribbean and in the Pacific (Johannes 1975, Dahl 1985, Rogers 1985). It is also a serious threat to reefs in Southeast Asia (e.g. Chansang et al. 1981, Hodgson \& Dixon 1988). In the western Atlantic, Caribbean and Pacific, dredging associated with construction of hotels, condominiums, runways, roads, and military installations and with beach replenishment has destroyed reefs, seagrass beds, and mangroves (Endean 1976, Jaap 1984, Dahl 1985, Salvat 1987, White 1987). Dredging near coral reefs and accelerated runoff of eroded soils increase turbidity, thereby cutting down light available for photosynthesis, as well as increasing sediment load on corals. Sediments which settle on coral colonies or 
which cause high turbidity while suspended in the water column have sub-lethal and lethal effects

Sometimes dredging and other activities which increase sediments in the water appear to cause only localized or negligible effects on corals (Brown \& Howard 1985). The dumping of 2200 tons of kaolin (clay) cargo from a freighter grounded on a reef in the Hawaiian Islands created large plumes of the suspended clay but had no apparent adverse effects beyond a radius of $50 \mathrm{~m}$ from the grounding site (Dollar \& Grigg 1981). Based on a brief qualitative survey, Sheppard (1980) suggested that dredging and blasting in Diego Garcia Lagoon (Indian Ocean) had resulted in a variable and low coral cover but no reduction in coral diversity. Construction of a boat harbor in Hawaii actually resulted in an overall increase in coral cover because of colonization of harbor surfaces (USACE 1983). In 1979, work began to extend the runway of the airport in St. Thomas (U.S. Virgin Islands) $726 \mathrm{~m}$ into water $27 \mathrm{~m}$ deep. Monitoring of fish populations, seagrass beds and coral reefs in the vicinity, over a 31 mo period, revealed no significant deterioration attributable to the plume from the dredge and fill operations (Rogers 1982). Sediments are less likely to cause a problem when strong currents are present as in this case. In some of these studies, more detailed or longer investigations might have revealed detrimental effects.

Decline of tropical fisheries, evident for the Caribbean (Rogers 1985) and the Pacific (Dahl 1985) is at least partially a result of degradation of coral reefs, seagrass beds, and mangroves from sedimentation. Increases in sedimentation rates can also alter the interactions between organisms and their habitats. Juveniles of many fish species and other organisms depend on mangroves and seagrass beds for food and shelter, moving to deeper waters and offshore reefs as they mature. Deterioration of any of these ecosystems can lead to a decline in fish populations. Cutting of mangroves trees which normally entrap sediments can result in excessive siltation for nearby seagrass beds and reefs from runoff after heavy rains. Destruction of red mangroves with submerged prop roots decreases the habitat for juvenile fishes (Thayer et al. 1987). Excessive sedimentation can affect the complex food web on the reef by killing not only corals, but also sponges or other organisms which serve as food for commercially important fish and shellfish

We know little of the effects of sedimentation on tropical marine systems other than coral reefs. Construction of airport runways led to burial of reefs and seagrass beds in Hawaii (Chapman 1979), Truk (W Pacific) (Amesbury et al. 1978) and Kosrae (W Pacific) (Maragos 1983). At Kosrae, Maragos (1984) noted burial of seagrass beds and reefs under up to $0.5 \mathrm{~m}$ of fine slurry muds that accumulated above mean low tide from pipeline dredging. Other seagrass beds in Kosrae were buried by sand suspended by cutterhead dredging. Penn (1981) noted that dredging of sand from seagrass beds in the Fiji Islands did not affect the seagrass beds adjacent to the sites of sand extraction, and seagrasses from the remaining beds helped to recolonize the dredged areas. Maragos (1983) reported that mangroves will not become re-established on dredged holes deeper than about $1 \mathrm{~m}$. We know almost nothing about the responses of seagrass beds and mangroves in cases where there is not complete burial.

Excessive sedimentation can adversely affect the structure and function of the coral reef ecosystem by altering both physical and biological processes (Fig. 1). The objectives of this paper are to review what we know about sediment effects on coral reefs and reef organisms, to suggest effective monitoring techniques, and to identify areas for further research. Knowledge of the precise effects of sedimentation is limited because of a lack of direct research. To date there has been no rigorous, comprehensive, before, during, and after study of the effects of dredging or terrestrial runoff on the structure and function of a coral reef. Quantitative data are scarce and much of the evidence of coral damage from sediments is circumstantial. At times, excessive sedimentation is just one of many stresses affecting a reef, making it difficult to differentiate the response to sediments from that to fresh-water, sewage, or drilling-fluid components (Pastorok \& Bilyard 1985). This review addresses our current inability to adequately predict the consequences of increasing sediment concentrations and rates of accumulation in marine waters at a time of unprecedented development in tropical coastal areas.

\section{SEDIMENTATION: ECOSYSTEM LEVEL EFFECT}

\section{Dredging}

The purpose of dredging is to obtain sand and corals for building materials or beach replenishment and to deepen navigation channels and harbors (DuBois \& Towle 1985). The magnitude and nature of the effects of dredging vary substantially depending on the equipment which is used (DuBois \& Towle 1985, Salvat 1987).

Dredging often affects not only the portion of the reef which is actually removed or smothered but also downstream areas where currents carry increased concentrations of fine suspended particles. Continual resuspension and transport of dredged sediments can cause reef degradation years after dredging ceases (Brock et al. 1966, Grigg et al. 1972, Marsh \& Gordon 1974) For example, dredging and filling destroyed 440 ha of reef 


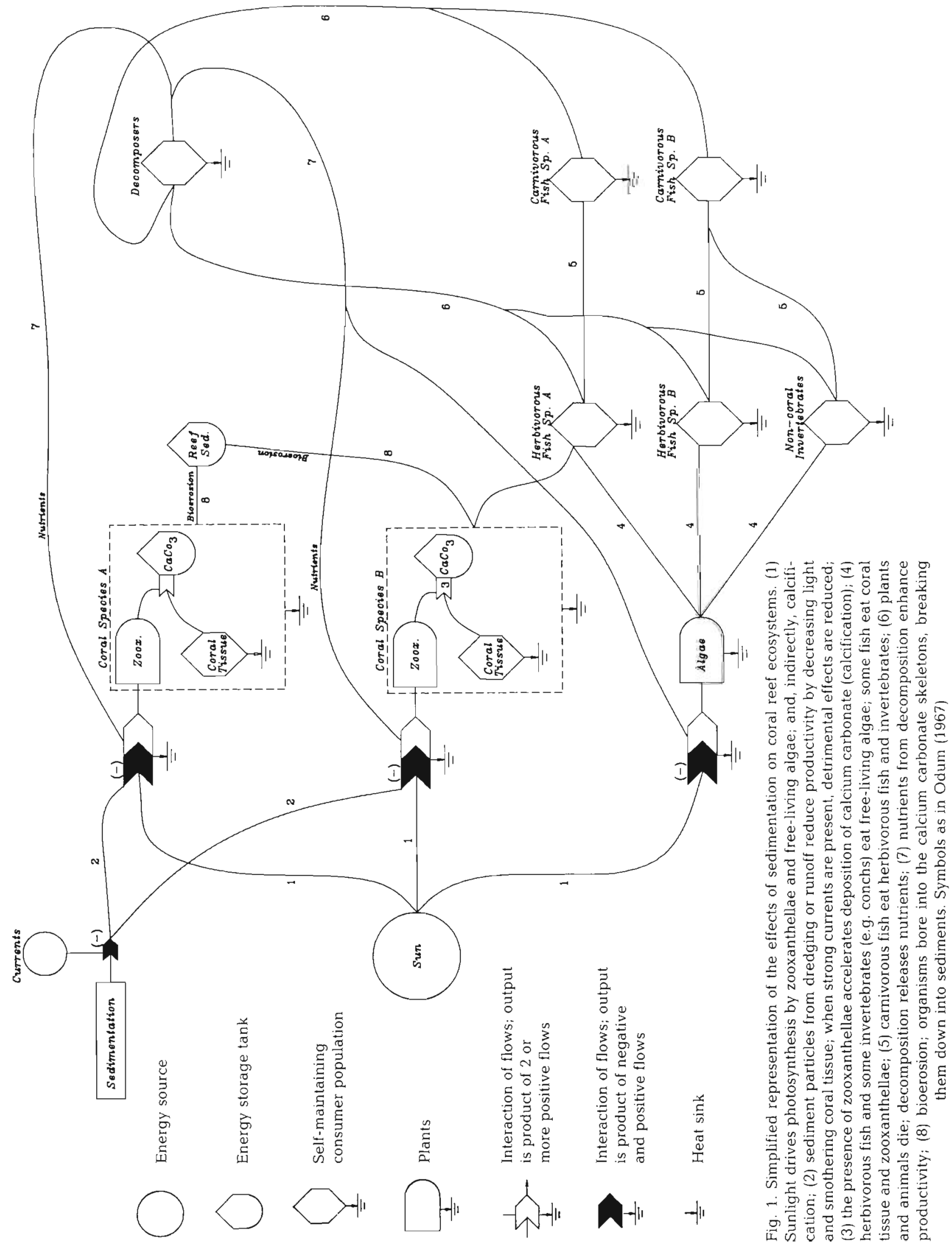


at Johnston Atoll and resulted in siltation which adversely affected 6 times this area (Brock et al. 1966).

In Bermuda, Dodge \& Vaisnys (1977) attributed lower amounts of living coral in Castle Harbor relative to other study reefs to extensive dredging $35 \mathrm{yr}$ earlier. Diploria labyrinthiformis was more abundant than $D$. strigosa, although the 2 species had been more evenly distributed before dredging. Hubbard \& Pocock's (1972) laboratory studies suggested that $D$. labyrinthiformis is more capable of rejecting sediments than $D$. strigosa. Dodge \& Vaisnys (1977) suggested that larger corals are more susceptible than small ones to damage from smothering by sediment particles because sediment removal from the colony surfaces is random and uncoordinated, resulting in a greater probability that particles would remain on a larger colony.

Florida's reefs are deteriorating partly as a result of intense economic pressures for upland development and beach replenishment (Jaap 1984, Voss 1988). Dredging, chemical and thermal pollution are all contributing to the demise of the reefs. In the Florida Keys in the 1960s and 1970s, numerous waterfront channels were dredged to obtain fill to elevate low-lying coastal areas for home construction. The dredge plume from one of these projects, off Key Largo, resulted in turbidity levels above $200 \mathrm{mg} \mathrm{l}^{-1}$ (Griffin 1974). The largest dredging projects now occurring in Florida are for beach replenishment. Blair \& Flynn (1988) quantified extensive mechanical damage to reefs from the drag head of the dredge used to obtain sand for the Sunny Isles Beach Restoration Project in southern Florida. The drag head was repeatedly pulled across the reefs adjacent to the sand deposits, resulting in some places in a damage tract up to $20 \mathrm{~m}$ across within which all benthic organisms were basically destroyed. At 2 sites a total of about $6000 \mathrm{~m}^{2}$ of reef was devastated. Marszalek (1981) surveyed reef areas before and after a large-scale dredging project off Florida and found that sea whips and other gorgonians were the most tolerant of the reef benthos mostly because their morphology prevented accumulation of sediments. No mass mortality of hard corals occurred, but an increased number of colonies exhibited symptoms of stress such as partial bleaching and excessive mucus secretion. Marszalek (1981) suggested that prolonged turbidity was more detrimental than shortterm accumulation of sediments.

Dredging for 10 mo (October 1986 to July 1987) caused heavy sedimentation on an intertidal reef in Thailand and decreased both living coral cover and species diversity (B. E. Brown unpubl.). More diverse areas with more susceptible coral species have been slower to recover. Rapid growth of injured colonies has led to rapid recovery with respect to living coral cover, although the number of coral species has not reached pre-dredging values.

\section{Runoff}

The amount of fresh-water runoff which enters the water will depend on (1) watershed size and slope, (2) volume and intensity of rainfall, (3) soil condition, and (4) land use (Hubbard 1987). Turbidity from runoff reduces the light available for photosynthesis by macroscopic and turf algae and endosymbiotic zooxanthellae within the tissues of corals, anemones, and other organisms, thereby affecting the overall metabolism of a coral reef. Rogers (1979) demonstrated that artificial shading of a portion of a reef in Puerto Rico, a partial simulation of extreme turbidity, resulted in bleaching of Acropora cervicornis, Diploria labyrinthiformis, and Montrastrea annularis colonies, a reduction in the growth rate of $A$. cervicornis, and a decrease in productivity. Some growing tips of A. cervicornis disintegrated.

Few detailed scientific assessments of the effects of runoff on coral reefs are available. In some cases, it is difficult to determine if death or bleaching from loss of zooxanthellae is a response to sediment particles or to fresh water. Excessive rainfall during a 1965 storm in Hawaii led to death of reef organisms from a combination of high turbidity, low salinity, and other factors (Banner 1968). Increased runoff after Hurricane Flora led to bleaching of corals, zoanthids, and sea anemones in shallow water off Jamaica (Goreau 1964). Increased river discharge may be responsible for the less than $2 \%$ coral cover on Algarrobo Reef off the west coast of Puerto Rico and for the accumulation of silt which killed all corals on a nearby reef (Morelock et al. 1983). Erosion of the shoreline and runoff from hillsides can result in the filling of shallow reef areas and the smothering of corals. The shoreline apparently extended $2 \mathrm{~km}$ across the reef flat in one Hawailan island because upland erosion was accelerated by farming (Moberly pers. comm. cited in Johannes 1975). Sometimes, apparently flourishing coral communities are found in naturally turbid conditions. For example, a turbid lagoon at Fanning Island (Central Pacific) had an abundance of primarily branching corals although the coral community was less diverse than in a clear lagoon with mostly massive and encrusting corals (Roy \& Smith 1971, Maragos 1974).

\section{Historical records of sedimentation on coral reefs}

Coral skeletons contain a historical record of sedimentation events because they trap terrigenous sediments (Cortes \& Risk 1984, Isdale 1984). Fluorescent bands of fulvic acids within the yearly growth bands are indicators of runoff, and large corals can provide a long record of runoff events (Isdale 1984). 
With pollen analysis and radiocarbon dating of sediments, it is possible to learn more about the processes of sedimentation which influence coral reef development. Nichols \& Brush (1988) assessed relative influences of human activities on natural sedimentation rates in a mangrove swamp near Reef Bay on St. John, USVI. Extensive deforestation in the 18th and 19th centuries on sugar cane plantations in the Reef Bay watershed apparently resulted in no dramatic changes in sedimentation rates. Presumably, in this case, nearshore coral reefs would not have suffered deleterious effects from increased sedimentation as a result of clearing of the hillsides. In a study of Reef, Fish and Hawksnest Bays, St. John, Hubbard et al. (1987) found a gradual reduction in coral growth over the last 100 to 200 yr (based on limited data from coral heads). In some cases, the growth decline corresponded to the period following intensive cultivation of the island. They suggest that recovery of the forests may have been accompanied by a decrease in the ability of the land to hold and retain sediment and water as more extensive vegetation (e.g. grasses) was shaded out by trees. Breakdown of the terracing systems from the plantation era could also lead to an increase in nearshore siltation. When trying to analyze the effects of historical and current land-clearing practices, it should be remembered that modern practices of clearing land with bulldozers that can remove topsoil down to underlying bedrock and completely uproot trees are potentially far more destructive than past methods

\section{Relation of sedimentation to coral and coral reef distribution}

Sedimentation is a major controlling factor in the distribution of reef organisms and in overall reef development (Hubbard 1986, Macintyre 1988). For example, reefs are generally better-developed, have more coral species, higher coral cover, and faster rates of framework accretion the farther they are from sources of runoff or the lower the sediment load in overlying waters (Randall \& Birkeland 1978, Morelock et al. 1983, Hubbard et al. 1987). However, because of the complexity of reefs and the numerous factors which affect growth and survival of corals, it is not necessarily valid to compare 2 areas and conclude that observed differences in coral community composition are due to different sedimentation rates. Documentation of a correlation of high sedimentation levels with a particular assemblage of coral species is not the same as demonstrating a causal relationship between this parameter and coral distribution patterns

Some of the confusion which arises when interpreting the composition of a coral community as a response to sedimentation levels is a result of assumptions that certain levels are 'high' and others 'low' (see below, 'Thresholds'). Also, use of different methods, particularly sediment traps of different types, has complicated interpretation and comparison of results from different sites. For example, traps with high height to aperture ratios will be less subject to resuspension of their contents than shallower traps. Traps placed on or just above the substrate collect more sediments than those higher in the water column (Ott 1975). Mean sedimentation rates for reefs which are not subject to stresses from human activities range from less than 1 to about $10 \mathrm{mg} \mathrm{cm}^{-2} \mathrm{~d}^{-1}$ (Table 1). In the absence of better information, we can suggest that chronic rates of greater than $10 \mathrm{mg} \mathrm{cm}^{-2} \mathrm{~d}^{-1}$ are 'high' (see also Pastorok \& Bilyard 1985). Confusion also arises over differential responses to reduced light from turbidity and smothering by sediment particles.

In reef zones with heavy sedimentation (whether from natural processes or human activities), one might hypothesize the following, relative to areas with less sedimentation: (1) lower species diversity, with some species absent; (2) less live coral (percent cover); (3) greater abundance of forms and species with greater resistance to sediment smothering or reduced light levels; (4) generally smaller coral colonies, because of their greater efficiency at rejecting sediments; or, (5) generally larger colonies, because sediments limit recruitment; (6) lower growth rates; (7) an upward shift in depth zonation: (8) a greater abundance of branching forms.

Average size of coral colonies on a particular reef may give little indication of the influence of sedimentation. On Cahuita Reef, Costa Rica, Cortes \& Risk (1984) found a correlation of heavy river discharge with lower diversity, lower cover, lower growth rates, and generally larger coral colonies. Maragos (1974) also found larger colonies in the turbid lagoon than in the clear lagoon at Fanning Island. Brown et al. (1986) speculate that fusion of Goniastrea colonies into larger colonies in shallow areas off Thailand could be a response to higher sedimentation rates. In contrast, smaller colonies were associated with high sedimentation rates in Puerto Rico (Loya 1976) and Bermuda (Dodge \& Vaisnys 1977).

Live coral cover and species diversity is much lower on the inner east wall of Salt River submarine canyon on St. Croix (USVI), than on the inner west wall where sedimentation rates are much lower (Hubbard 1986). However, these 2 parameters are similar on the more seaward, outer portions of the walls where rates of sedimentation are comparable (Rogers et al. 1984).

At Cahuita Reef, Costa Rica, characterized by heavy sedimentation rates (Table 1), the abundant corals were Agaricia agaricites, Siderastrea radians, and Porites porites (Cortes \& Risk 1984). Loya (1976) 
Table 1. Comparison of sedimentation rates and turbidity levels for different reefs

\begin{tabular}{|c|c|c|c|c|}
\hline Location & $\begin{array}{c}\text { Rates } \\
\left(\mathrm{mg} \mathrm{cm}^{-2} \mathrm{~d}^{-1}\right)\end{array}$ & $\begin{array}{l}\text { Total suspended } \\
\text { solids (mg } 1^{-1} \text { ) }\end{array}$ & Comments & Source \\
\hline \multicolumn{5}{|l|}{ Caribbean } \\
\hline Jämaica (Discovery Bay) & $\begin{array}{c}0.5-1.1 \\
\text { (means for traps } 50 \mathrm{~cm} \\
\text { above substrate) }\end{array}$ & & $\begin{array}{l}\text { Reef lagoon, } \\
\text { ca ( } 4 \text { m deep) }\end{array}$ & Dodge et al. (1974) \\
\hline \multirow[t]{2}{*}{ St Thomas, USVI } & $\begin{array}{c}0.8 \pm 0.4-5.8 \pm 13.3 \\
\text { (means } \pm \text {-SE for traps } \\
10 \mathrm{~cm} \text { above the } \\
\text { substrate) }\end{array}$ & & $\begin{array}{l}\text { Five coral reef areas, } \\
\qquad 3-5 \mathrm{~m} \text { deep }\end{array}$ & Rogers (1982) \\
\hline & $\begin{array}{c}0.1 \pm 0.1-1.6 \pm 0.7 \\
\text { (means } \pm S E \text { for traps } \\
50 \mathrm{~cm} \text { above the sub- } \\
\text { strate) }\end{array}$ & & & \\
\hline Puerto Rico & $1-15$ & & Reef $9-33 \mathrm{~m}$ deep & Cintron et al. (1974) \\
\hline \multirow[t]{2}{*}{ Puerto Rico } & $\begin{array}{c}2.5 \pm 0.9-2.6 \pm 1.2 \\
\text { (means } \pm S E \text { for traps } \\
50 \mathrm{~cm} \text { above the sub- } \\
\text { strate) }\end{array}$ & 0.8 & Backreef $4 \mathrm{~m}$ deep & Rogers (1983) \\
\hline & $\begin{array}{c}9.6 \pm 2.4 \\
\text { (means } \pm \mathrm{SE} \text { for traps } \\
10 \mathrm{~cm} \text { above the sub- } \\
\text { strate) }\end{array}$ & & & \\
\hline Costa Rica (Cahuita) & $30-360$ & & & Cortes \& Risk (1984) \\
\hline Barbados & $<10$ to $>40$ & 4.3 to 73 & & Tomascik \& Sander (1985) \\
\hline \multirow[t]{2}{*}{ Barbados } & $\begin{array}{c}\text { ca } 5 \text { to } 10 \\
\text { (means for traps } \\
\text { ca } 5 \mathrm{~cm} \text { above the sub- } \\
\text { strate }-7 \text { stations) }\end{array}$ & & Barrier reef $13.5-45 \mathrm{~m}$ & Ott $(1975)$ \\
\hline & $\begin{array}{c}1 \\
\text { (means for traps ca } 1 \mathrm{~m} \\
\text { above the substrate - } \\
1 \text { station) }\end{array}$ & & & \\
\hline \multicolumn{5}{|l|}{ Pacific } \\
\hline Hawaii (Kaneohe Bay) & $35-41096, x=3498$ & & $\begin{array}{l}\text { Rates from lagoon } \\
\text { slopes, stations } 6 \mathrm{~m} \\
\text { deep or less; reefs } \\
\text { subjected to several } \\
\text { stresses, including } \\
\text { heavier than normal } \\
\text { runoff during } \\
\text { study }\end{array}$ & Maragos (1972) \\
\hline
\end{tabular}

reported higher cover by Meandrina meandrites, Montastrea cavernosa, Siderastrea radians, and Diploria strigosa, fewer coral species, and less overall live cover on a reef receiving up to $15 \mathrm{mg} \mathrm{cm}^{-2} \mathrm{~d}^{-1}$ than on a nearby reef with less sedimentation.

In 1983, Morelock et al. (1983) reported that Algarrobo reef and Escollo Rodriguez reef off the west coast of Puerto Rico were being buried by silt. At Algarrobo, only Porites astreoides, Montastrea Cavernosa, and Millepora alcicornis were present, and live coral cover was less than $2 \%$. Heavy sedimentation at these reefs was attributed to increased discharge from rivers and erosion resulting from agriculture and development.
In a study of the distribution of coral communities located near 2 rivers in Guam, Randall \& Birkeland (1978) concluded that observed decreases in natural sedimentation rates along a gradient from the river mouths to the open sea explained the increase in number of coral species, from less than 10 to over 100 , and number of genera, from less than 10 to 35 and above. Percent living coral cover increased from less than 2 to over 12 along the same gradient. The authors predicted that sedimentation rates ranging from 162 to $216 \mathrm{mg} \mathrm{cm}^{-2} \mathrm{~d}^{-1}$ will be associated with less than 10 species while rates from 5 to 32 will be correlated with over 100 coral species (data converted from original). 
Because of the variety of environmental factors which can affect coral growth and distribution, caution should be used in interpreting observed distribution patterns as responses to single factors such as sedimentation and in extrapolating findings to other locations.

The importance of bottom topography in determining coral distribution should not be underestimated. Highest coral diversity is often associated with forereef slopes (Porter 1972, Sheppard 1982), presumably at least partly because sediments do not accumulate as easily in these areas. Around the island of St. John, numerous fringing reefs exhibit relatively high coral cover where they slope steeply to about $10 \mathrm{~m}$ to end abruptly on a flat sandy or algal plain. However, in a few locations where deeper water is close to shore and a sloping bottom exists, vigorous coral growth is found to at least $30 \mathrm{~m}$ (C. Rogers pers. obs.).

Adey et al. (1977) provided an interesting geological perspective on development of western Atlantic reefs and further evidence of the way sedimentation controls reef growth. They suggested that high turbidity and nutrient levels, which resulted from erosion of Pleistocene shelves, caused deterioration of shallow Acropora palmata reefs over 7000 yr ago. As water quality improved, coral species better adapted to the deeper water established communities on these relict reefs. Hubbard et al. (1986) noted a dramatic change in the style and rate of reef accretion along the margins of Salt River submarine canyon, St. Croix, related to formation of the Salt River estuary 5000 to $6000 \mathrm{yr}$ ago. Subsequently, accretion has slowed substantially in response to increased levels of suspended sediments.

\section{Recruitment}

Sedimentation is one of several parameters which affect coral recruitment (Birkeland 1977, Bak \& Engel 1979, Birkeland et al. 1981, Rogers et al. 1984\}. Coral larvae tend to settle on vertical surfaces possibly in response to higher sedimentation rates, as well as competition with algae, and other factors (Birkeland 1977. Rogers et al. 1984). Coral larvae cannot successfully establish themselves in shifting sediments. Increases in sediment input (either in suspension or as accumulating particles) could radically alter the distributions of reef organisms by influencing the ability of their larvae to settle and survive. Tomascik \& Sander (1987) suggest that lower light levels may inhibit development of coral larvae by reducing the amount of energy available to maturing ova or embryos. They found reduced numbers of larvae from colonies of Porites porites growing on reefs polluted by nutrients and suspended particulate matter.

\section{SEDIMENTATION EFFECTS AT THE ORGANISM LEVEL}

Although burial of corals generally leads to death after a number of hours (Mayer 1918, Marshall \& Orr 1931), some species can withstand applications of large amounts of sediments in the laboratory (Edmondson 1929, Hubbard \& Pocock 1972, Bak \& Elgershuizen 1976, Lasker 1980) and in the field (Edmondson 1929, Marshall \& Orr 1931, Lasker 1980, Rogers 1983). Corals have a variety of mechanisms for coping with sediments including use of their tentacles and cilia, stomodeal distension through uptake of water, and entanglement of particles in mucus which later sloughs off the colony surface (Hubbard \& Pocock 1972). Corals exhibit both active and passive removal of sediment particles (Lasker 1980). Where currents are strong, water movement will help to keep sediment particles from settling on colony surfaces, and corals will have to spend less energy in sediment rejection.

Species differ in their ability to reject sediments, with colony and calyx morphology playing an important role (Hubbard \& Pocock 1972). Colonies of Agaricia agaricites and Montastrea annularis exhibit changes in orientation and morphology which appear to reflect adaptations to sediment stress (Bak \& Elgershuizen 1976). Logan (1988) suggests that the frequently observed orientation of the large calyx in Scolymia cubensis at a steep angle from the horizontal may be an adaptation which facilitates sediment removal.

Field observations are sometimes contradictory and at times appear to differ from laboratory results. For example, laboratory experiments (Hubbard \& Pocock 1972, Bak \& Elgershuizen 1976) indicated that Porites astreoides would be inefficient or only moderately good at rejecting sediments, relative to other species, but Morelock et al. (1983) and Cortes \& Risk (1984) found it one of the most abundant species in heavily sedimented areas. In contrast, Bak (1978) documented susceptibility of this species to dredging. Meandrina meandrites rejected sediments very efficiently in Bak \& Elgershuizen's (1976) laboratory experiments, but were incapable of rejecting any sediments in Hubbard \& Pocock's (1972) studies. Additional studies in the field and laboratory using standardized methods with close attention to growth habitat might resolve some of the apparent discrepancies.

In a study of San Cristobal reef, Puerto Rico, Rogers (1983) found that sediment particles could not adhere to the cylindrical branches of Acropora cervicornis but were able to accumulate on flat portions of Acropora palmata. Calcareous sediments were applied in situ to colonies of Montastrea annularis, Diploria strigosa, $D$. clivosa, A. palmata, and A. cervicornis in different frequencies and doses. A. palmata was the most sensi- 


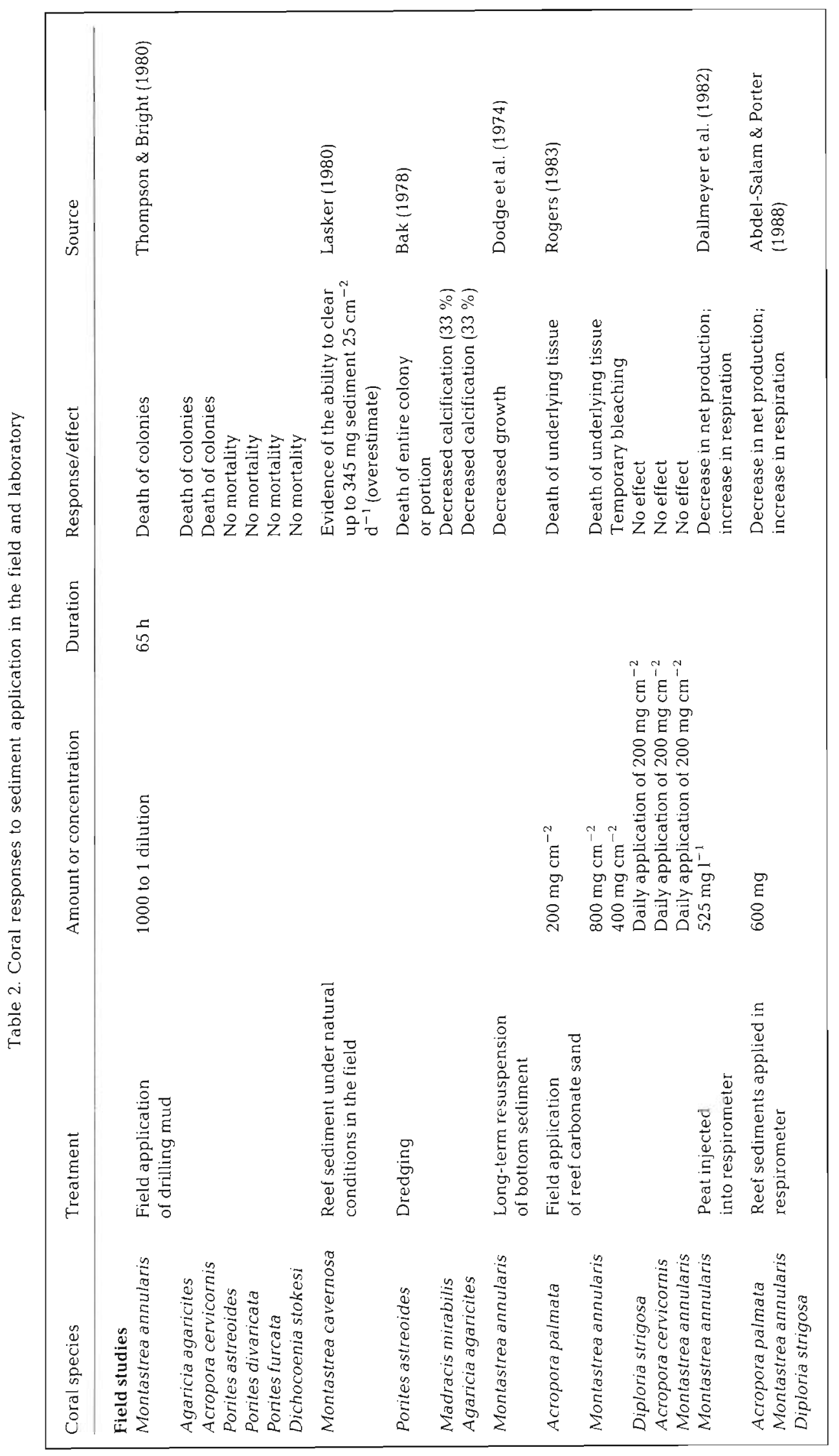




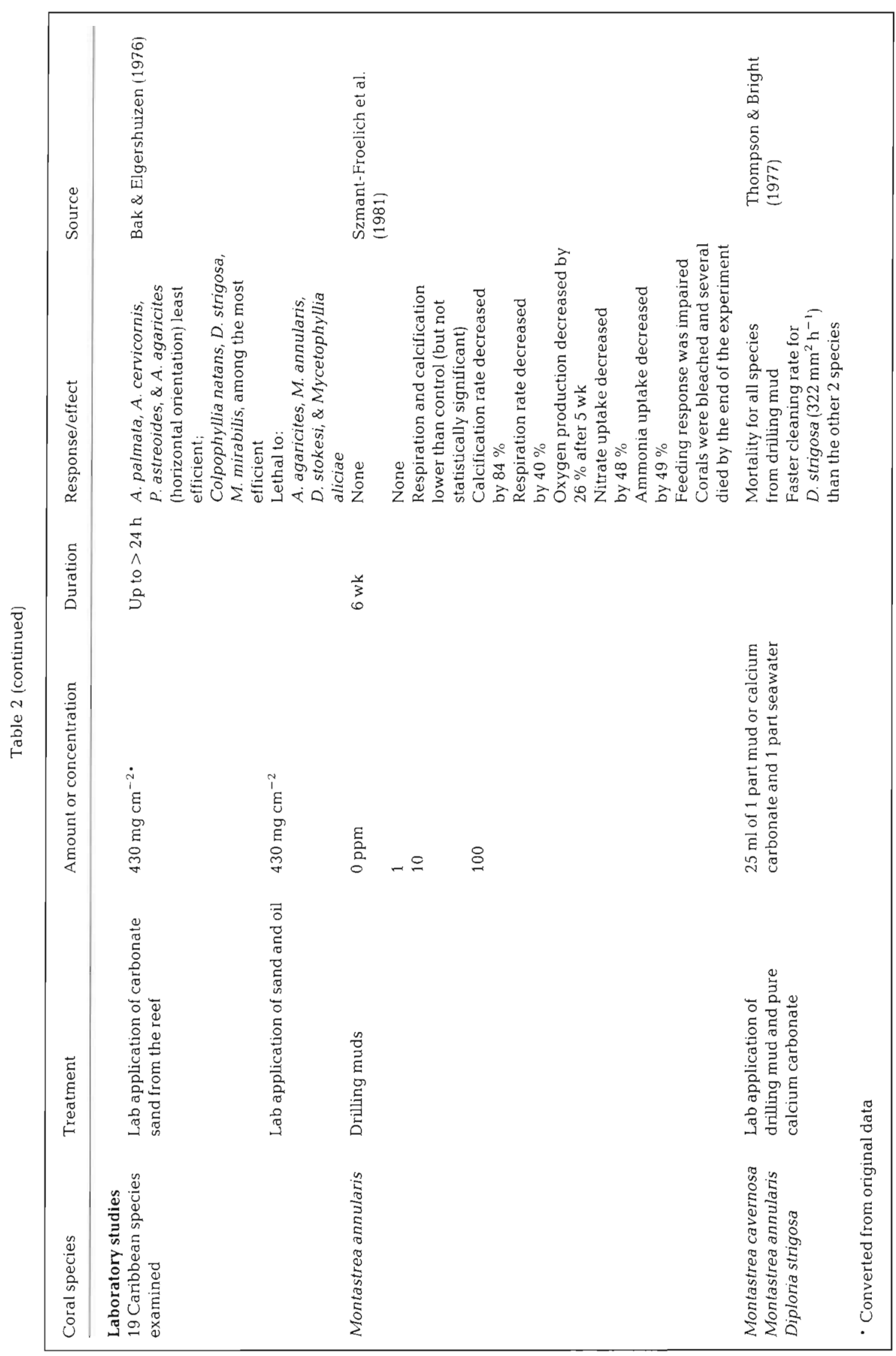


tive of the species tested. Single applications of $800 \mathrm{mg}$ $\mathrm{cm}^{-2}$ to $M$. annularis colonies and $200 \mathrm{mg} \mathrm{cm} \mathrm{cm}^{-2}$ to $A$. palmata colonies caused death of underlying coral tissue, while the other experimental species were not significantly affected by any of the doses. The differential response of $A$. cervicornis and $A$. palmata to sediment application implies we cannot assume that branching corals are generally more tolerant than head corals to sediment stress although for some species this appears to be the case (Chappell 1980). Response will probably differ depending on whether the stress is from reduced light levels from high turbidity or from accumulating particles. For example, A. cervicornis was the most susceptible species to shading in Rogers' (1979) experiment.

Dredging near a fringing reef in Curaçao resulted in mortality of portions or entire colonies of Porites astreoides (at depths of 15 to $25 \mathrm{~m}$ ) and decreased calcification rates for Madracis mirabilis and Agaricia agaricites, with calcification remaining suppressed for over 1 mo after the turbid water cleared up (Bak 1978). The apparent cause was reduction of light levels to only $1 \%$ of surface illumination.

Although we might expect smaller-polyped 'autotrophic' corals which depend more on light to succumb more quickly to turbid conditions than large-polyped corals which rely more on plankton as an energy source, we lack data either to conclusively support the validity of separating corals into 'autotrophic' and 'heterotrophic' categories (Porter 1976) or to test the hypothesis of differential sensitivity. Montastrea cavernosa (with large calices), and Siderastrea siderea and the Pacific coral Porites lutea (both with small calices), are relatively tolerant of high levels of sedimentation (Lasker 1980, Maragos pers. comm.).

There are few data on the susceptibilities of different coral species to suspended sediments. Maragos (unpubl.) indicates that several Pacific species, including many with large polyps, are less sensitive than other species and suggests that corals normally found in shallow near shore areas will be more resistant than those on seaward reefs. Examination of a table presented in Randall \& Birkeland (1978) suggests that the following Pacific corals are relatively resistant to high sedimentation, based on their occurrence in areas where the highest sedimentation rates were recorded: Pocillopora damicornis, Montipora verilli, Porites lutea. Brown (unpubl.) found that $P$. Iutea was less susceptible to the effects of dredging at a site in Thailand than some of the faviid species.

In a simulation of extreme turbidity, the shading of a section of a coral reef off Puerto Rico, Rogers (1979) found that Acropora cervicornis colonies were the most sensitive, followed roughly by species with mediumsized calices (Montastrea annularis, Diploria labyrin- thiformis, and Diploria strigosa) and species with larger calices (e.g. M. cavernosa). In this experiment, corals did not have the usually concurrent problem of sediment removal.

Synthesis of field and laboratory observations (Table 2) suggests the following: (1) Different species have different capabilities of clearing themselves of sediments or surviving lower light levels. (2) The amount and type of sediment will influence the ability of a coral to reject sediments which settle on the colony surfaces. (3) Sediment rejection is a function of morphology (of the whole colony, the calices, and the colony surface), orientation (vertical, horizontal), and behavior. (4) Experimental corals may not respond normally in the laboratory.

\section{Changes in coral growth with increases in sedimentation}

The growth of a coral skeleton is the end result of several physiological processes which can be altered by environmental conditions. It is not always clear what triggers specific growth responses in corals. Coral growth does not appear to be a simple indicator of excessive sedimentation. Skeletal growth is a function of linear extension, bulk density, and calcification, parameters which can vary independently (Barnes \& Crossland 1980, Gladfelter 1982, 1983, Dodge \& Brass 1984). Growth can vary greatly between colonies of the same species under similar environmental conditions and even within a single colony (Rogers 1979, Brown \& Howard 1985). This variability makes rigorous statistical analysis and interpretation of results difficult. Dodge (1982) exposed Montastrea annularis colonies to drilling fluid and found decreases in the length of the septa, columella, endothecal base, and fossa. However, Foster (1980) did not find a simple relationship between fossa length and sedimentation levels.

Because corals and associated zooxanthellae depend on light for rapid deposition of calcium carbonate (Chalker 1981), high turbidity can reduce coral growth rates. Growth may also decrease because of the diversion of energy to removal of sediment particles. Dodge et al. (1974) described the inverse correlation between natural sedimentation and Montastrea annularis growth rates. Growth rates of this species from the East Flower Gardens Bank reef in the Gulf of Mexico were negatively correlated with discharge of sediments and fresh-water from the Atchafalaya River (Dodge \& Lang 1983)

Hubbard et al. (1987) documented a correlation between short-term decreases in Montastrea annularis growth and construction in the watershed of Hawksnest Bay, St. John. Hubbard \& Scaturo (1985) found that 
growth rates of 7 coral species from Cane Bay and Salt River, St. Croix (USVI), decreased with depth and suggested that turbidity and sedimentation were among the major controls of growth rate. Colonies of $M$. annularis grew faster at Cane Bay than at corresponding depths at Salt River where concentrations of suspended materials are consistently higher. Examination of growth bands suggested slower growth of Diploria colonies in Bermuda for several years prior to death from siltation associated with dredging (Dodge \& Vaisnys 1977).

Tomascik \& Sander (1985) investigated the effects of water quality on Montastrea annularis growth rates off Barbados over a gradient of increasing eutrophication (primary sewage, industrial effluent). They found that mean concentration of suspended particulate matter ( $\mathrm{mg} \mathrm{l}^{-1}$ ) was the strongest single estimator of growth rates, with the most rapid coral growth occurring at the site farthest from the primary pollution source.

Sometimes, some of the corals in an area die from sedimentation, although surviving colonies show no decline in growth. Hudson et al. (1982) noted little suppression of growth in Porites lutea colonies from an area around an oil drilling site although they attributed a 70 to $90 \%$ reduction in colonies of several species to smothering by drill cuttings. Brown et al. (unpubl.) noted that increased sedimentation on a coral reef in Thailand led to death of $30 \%$ of the $P$. lutea colonies but no evidence of decreases in linear growth of remaining colonies of this species.

\section{Changes in coral growth form with increases in sedimentation}

Sedimentation can affect not only growth rates but also colony morphology. Foster $(1979,1980)$ has shown that Montastrea annularis colonies exhibit changes in their skeletal morphology when transplanted to locations with higher sedimentation rates. Hubbard et al. (1987) suggest the multi-lobed, knobby growth form of this species may reflect sediment stress. In studies off St. John, they found this form consistently grew closer to sources of runoff and was common in backreef areas. Barnes (1973) speculated that the sides of a colony could approach a critical radius because they receive less light than the upper colony surface. A columnar growth form could result, with this column later dividing into units of smaller radius. This process of column formation and isolation could be accelerated by sediment particles settling in concave areas of the colony surface and killing the underlying tissues. The flattened or plate-like growth form of $M$. annularis which appears to be an adaptation to low light intensities (Dustan 1975) would be less efficient at removing sediments than a more rounded form.
Some corals may fuse in response to increased sedimentation (Brown et al. 1986). Hughes \& Jackson (1985) reported higher survival rates for colonies which fused than for those which arose from fission of larger colonies in reefs off Jamaica.

\section{Changes in coral metabolism with increases in sedimentation}

Particles in suspension in the water can alter both intensity and spectral quality of light reaching reef organisms, thereby affecting their metabolism. Few studies of coral metabolic responses to sediment stress have been conducted. Rogers (1979) shaded a portion of San Cristobal reef (Puerto Rico) to simulate the shading effects of turbidity and found decreased net productivity by the coral community. Edmunds \& Davies (1986, 1989) calculated energy budgets for Porites porites colonies growing at 2 sites off Jamaica. Colonies growing at the site with lower light levels and higher sedimentation rates had lower growth rates but higher productivity because of photoadaptation. It would be interesting to determine energy budgets for $P$. porites colonies growing in areas with much higher sedimentation rates than those reported in this study.

Using a respirometer, Dallmeyer et al. (1982) found a decrease in net production by Montastrea annularis colonies exposed to particulate peat during daytime experiments. At night, colonies exhibited increased respiration and active clearing behavior. Colonies of Acropora palmata, Montastrea annularis, and Diploria strigosa showed significant increases in respiration and decreases in net photosynthesis following application of sediments from a road construction site in other respirometer studies off St John, USVI (Porter \& Rogers unpubl.). These species responded in similar ways to doses of carbonate reef sediments in experiments off $\mathrm{St}$ Croix, USVI (Abdel-Salam \& Porter 1988). The terrigenous sediments had more pronounced effects on both respiration and photosynthesis. The integrated $\mathrm{P} / \mathrm{R}$ ratios for all sediment-treated corals in the St Croix study were $<1$.

\section{Effects of drilling fluids on coral reef organisms}

The search for additional supplies of oil and natural gas has led to a dramatic increase in offshore drilling and concern over the possibly detrimental effects of discharged drilling fluids (used to remove drill cuttings and to lubricate drill bits). In their comprehensive review of the effects of these fluids on reef corals, Dodge \& Szmant-Froelich (1985) note that there is 'no clear-cut separation between effects due to sedimenta- 
tion alone versus those caused by potentially toxic chemical constituents, or due to a synergism between the two'.

Exposure of corals (Montastrea annularis and other species) to drilling fluids can cause death (Thompson 1979, 1980), alter feeding behavior (Szmant-Froelich et al. 1981), disrupt the normal pattern of polyp expansion and retraction (Thompson \& Bright 1980), alter physiology (Krone \& Biggs 1980), cause morphological changes (Foster 1979, 1980) and lower the density of zooxanthellae (Szmant-Froelich et al. 1981). Calcification appears to be one of the first processes disrupted by exposure to drilling fluid (Szmant-Froelich et al. 1981). In many of the experiments cited above, a drilling fluid concentration of $0.100 \mathrm{ml} \mathrm{l}^{-1}$ appeared to be critical with lower concentrations eliciting little or no response. Hudson et al. (1982) attributed a 70 to $90 \%$ reduction in coral cover of several species in the Philippines to drilling several years previous to their study. Dodge \& Szmant-Froelich (1985) conclude that sensitivity to drilling fluid may vary widely among species, within species, and with the type and amount of fluid tested.

\section{RELATION OF SEDIMENTATION TO CORAL REEF FISHES}

Sedimentation can alter the complex interactions between fish and their reef habitat. Fish graze on dead coral, breaking down the calcium carbonate skeleton and producing large quantities of sediment; provide nutrients in their wastes; and graze on coral larvae, thereby influencing the reef's structure. Randall (1974) suggested that the continuous rain of sediments from parrotfishes and surgeonfishes adversely affects reef organisms. However, fish faeces may enhance coral growth (Meyer et al. 1983) and supply essential nutrients (Szmant-Froelich et al. 1981). In a synthesis of studies of the effects of fish grazing on coral reef structure, Hixon (1986) noted that damselfish which defend algal territories directly influence coral recruitment and growth, as well as bioerosion. Numerous studies demonstrate the effects of fish grazing on reef algae (e.g. Ogden \& Lobel 1978). Economically important fish (e.g. snappers, grunts) and conchs feed on the benthic microalgae and invertebrates in reef sediments.

The highest number of fish species and greatest abundance of individuals tend to be associated with forereef zones or other areas which provide the greatest topographical relief and structural complexity (e.g. Risk 1972, Luckhurst \& Luckhurst 1978, Gladfelter et al. 1980, Boulon 1987). The death of major reef-building corals, from sedimentation, disease, or other causes, can lead to collapse of the reef framework itself as organisms bore into and weaken the substrate (Hedley 1925, Sano et al. 1987). With a decline in the number of crevices and hiding places that the reef provides, there is a reduction in both the number of individuals of fish and the number of species that the reef can sustain. This decrease in both the number of fish and the number of species could be a function of a reduction in the amount of living coral cover as well as a decrease in the amount of shelter the reef can provide (Bell \& Galzin 1984). Sano et al. (1987) found more species and individuals of fish on a living (mostly Acropora spp.) reef than on a primarily dead reef which had low structural relief following an Acanthaster planci infestation. Apparently, there was a further decline in fish abundance and diversity as the dead reef collapsed into rubble 2 yr later. Maragos (pers. comm.) notes that fishermen in Kosrae reported their catch dropped by half following burial of some reefs and seagrass beds.

Dredging apparently can lead to a decrease in fish diversity, but data are limited. Galzin (1981) reported that resumption of dredging in Grand Cul de Sac Marin, Guadeloupe (West Indies), led to the disappearance of 20 fish species out of a total of 29 which were observed (during a single census) after dredging had ceased for over a year. Fewer fish species were associated with areas near dredge sites. A loss in living coral cover rather than a loss of topographical relief may have been responsible for the suspected decline.

Amesbury (1981) found that the number of fish species decreased significantly at monitoring stations near a runway construction site in Truk where fine sediments had accumulated from dredging and filling activities. Burial of one coral mound resulted in disappearance of all the fish, while partial burial of another patch reef led to decline of $50 \%$ of the species. He noted that territorial fish species and those with limited ranges remained even under conditions of high turbidity and suggested that fish behavior was not a very effective indicator of environmental degradation. At Johnston Atoll (Central Pacific), the disappearance of 12 species of Chaetodontidae (butterflyfishes) which eat coral was correlated with extensive death of the corals from siltation associated with dredging (Hourigan et al. in press).

Herrnkind et al. (1988) studied the effects of siltation on spiny lobster (Panulirus argus) recruitment in the Florida Keys, USA. Following a series of laboratory experiments and field surveys, they concluded that the relative lack of juvenile lobsters in heavily silted areas was a result of both lower postlarval settlement and actual avoidance of algal habitats with high silt loads. Clumps of the red alga Laurencia spp. are preferred habitat for newly settled postlarval lobsters. Fewer prey 
items (e.g. gastropods and amphipods) are found in algal clumps with large amounts of trapped silt. Silt apparently did not have an effect on survival of pueruli through metamorphosis to the first benthic stage or on time to metamorphosis. Herrnkind et al. (1988) note that most of the silt in their survey areas was calcareous, probably resulting from biological sediment processing. However, they suggest that human activities which introduce siltation into marine waters or accelerate normal siltation rates are detrimental to spiny lobster recruitment.

\section{RECOVERY AFTER SEDIMENT STRESS}

Few examples of recovery of coral reefs after severe sediment damage have been documented. With respect to recovery and recolonization of reefs, Brown \& Howard (1985) suggest that 'both generalizations and predictions are dangerous'. They recommend consideration of each case individually. Sometimes increased sedimentation is accompanied by other stresses, prolonging or inhibiting recovery. Maragos (1972) estimated that $80 \%$ of the coral communities in the lagoon in Kaneohe Bay, Hawaii, died because of a combination of dredging, increased sedimentation, and sewage discharge (see also Roy 1970). Six years after discharge of sewage into Kaneohe Bay ceased, dramatic recovery of corals and a decrease in the growth of the smothering alga Dictyosphaeria cavernosa were reported (Maragos et al. 1985). Maragos et al. (1985) suggest that the sewage had delayed or prevented recolonization of corals on dredged surfaces by stimulating growth of algae which competed with corals for space.

\section{RECOMMENDATIONS FOR MONITORING SEDIMENT STRESS}

Peters \& Pilson (1985) provide a list of methods for monitoring coral stress responses which includes visual, physiological, and histopathological examination (Table 3). Their study of the response of Astrangia danae to sediments is one of the few to date which incorporates histological examination.

One useful and inexpensive monitoring technique is the successive observation and photography of individual coral colonies over time to reveal sediment smothering, algal overgrowth, disease or bleaching. Colonies should be selected randomly and identified with numbered plastic tags using plastic cable ties to secure them to the substrate near the coral or to concrete nails driven into the substrate. Corals have annual growth bands and patterns of growth which can sometimes be correlated with changes in water quality or other environmental disturbances (Dodge et al. 1974, Hudson 1981). However, the colonies which are analyzed are the survivors and therefore possibly poor indicators of stress. Further calibration of growth with different conditions will make 'sclerochronology' even more useful. Successful establishment and growth of coral recruits presumably indicates sedimentation rates are not at a detrimental level.

No simple relationship exists among water transparency (\% light transmission, Secchi disk depths), nephelometer turbidity units, suspended matter concentrations, and sediment deposition rates (Jerlov 1970). When feasible, all of these should be measured. When resources are limited, water samples can be filtered for calculations of suspended matter concen-

Table 3. Methods for monitoring coral responses to sedimentation (adapted from Peters \& Pilson 1985)

Visual observations (behaviour and appearance)

1. Unusual polyp contraction or expansion

2. Extrusion of mesenterial filaments

3. Unusual mouth opening responses

4. Change in feeding behaviour

5. Increased mucus production/muco-ciliary activity

6. Decrease in zooxanthellae concentration ('bleaching')

7. Appearance of bare skeleton or abnormal tissue growth (e.g. lesions)

8. Appearance of accumulations of layers of sediments over living portions of colony

Physiological measurements

1. Variation in metabolic rate based on respiration

2. Change in excretion rate/excretory products

3. Differences in biochemical composition

4. Decrease on increase in calcification rates (growth rates)

5. Change in photosynthesis by zooxanthellae

Histopathological examinations

1. Reduced gonad development or change in reproduction cycle

2. Change in morphology and/or composition of tissues and cells, abnormal accumulations of biogenic deposits

3. Presence of microparasites or pathogens 
trations. The quantity and quality of light reaching photosynthetic reef organisms should be measured when possible.

\section{PREDICTING THE EFFECTS OF COASTAL DEVELOPMENT ON CORAL REEFS}

Dredging is not likely to cease especially in small developing tropical islands and countries where other sources of building materials are inaccessible. Hillsides will continue to be cleared of vegetation to make way for more and more shoreline development. Consequently, we must find the most effective ways to predict and to limit the consequences. Often the careful planning and implementation of protective measures during construction projects can reduce damage to marine systems (DuBois \& Towle 1985, White 1987). For example, use of silt screens, settling ponds, and berms can reduce adverse effects (Salvat 1987, White 1987. Maragos 1989). Natural drainage patterns should be altered as little as possible. Developers should be required to monitor the effects of coastal construction on nearby marine ecosystems as a condition of their permits.

In some cases, scientists are hindered in their evaluation of the consequences of a particular coastal project because of a lack of information on basic coral biology and the lack of even simple models to aid in prediction of environmental responses. Necessarily vague scientific assessments of possible impacts (e.g. from hotel construction on a beach with an offshore reef) are easy to ignore in the face of more definitive, concrete economic benefits.

It is essential to incorporate environmental considerations into coastal zone management decisions. Hodgson \& Dixon (1988) provide an interesting evaluation of alternative plans for the development of the area of Bacuit Bay, Palawan (Philippines) where nature-based tourism (primarily SCUBA diving) and marine fisheries are in conflict with the logging industry. Clearing of trees and building of logging roads have increased sheet erosion and introduced high levels of sediment into the bay. Hodgson \& Dixon (1988) found that high rates of sediment deposition significantly reduced coral cover and diversity, with a reef closest to the mouth of a river which empties into the bay losing almost half its live coral following heavy rainfall. Based on a $1 \mathrm{yr}$ study, these authors predict an annual decrease in coral cover of $1 \%$ for every additional $400 \mathrm{mt} \mathrm{km}^{-2}$ of sediment deposition in Bacuit Bay; an annual loss of one coral species per increase of $100 \mathrm{mt} \mathrm{km}^{-2}$ sediment deposition; and a decrease of $2.4 \%$ in fish biomass for each $1 \%$ decrease in coral cover Using a model based on these results and various assumptions, e.g. about degradation of water quality with continued logging, Hodgson \& Dixon (1988) concluded that the predicted increase in revenue from logging was less than the loss in income to tourism and fisheries resulting from degradation of the marine systems.

\section{FUTURE RESEARCH NEEDS}

More rigorous, comprehensive research is needed to quantify the response of individual reef organisms and the reef system as a whole to sedimentation from dredging and watershed development (runoff). Ideally, scientists should conduct a multidisciplinary study to augment our understanding of how increases in sedimentation alter the structure and function of coral reefs and associated marine ecosystems. Emphasis should be on changes in abundance and spatial arrangement of dominant benthic organisms. If scientists are going to effectively assess changes and trends on coral reefs, they must start using standardized monitoring methods. Long-term data sets are absolutely necessary for these complex ecosystems.

The interactions and linkages among mangroves, seagrass beds, and coral reefs require further study, along with the effects of sedimentation on these interactions. More studies on the life cycles of fishes and their dependence on the major ecosystems are a prerequisite for effective fisheries management. We need to know more about how fish and shellfish depend on and influence their habitats at different stages of their life cycles. We need to discover how pollution, sedimentation from runoff and dredging, and other stresses from human activities affect (directly and indirectly) the organisms, the food webs, the habitats and the interactions among them. Exactly what is the connection between habitat degradation and fisheries decline?

\section{Thresholds}

Further research is needed on the threshold levels for individual reef species (hard corals, soft corals and others) and for the reef ecosystem as a whole - the levels above which sedimentation has lethal effects for particular species and above which normal functioning of the reef ceases. With reference to experiments on individual organisms, we need more studies on corals other than Montastrea annularis. What turbidity level (concentration of total suspended solids) will result in a given percent decrease in the amount of living coral cover? What sedimentation levels cause death of coral species in the field? 'Normal' sedimentation rates for coral reefs appear to be on the order of $10 \mathrm{mg} \mathrm{cm}^{-2} \mathrm{~d}^{-1}$ or less, and typical suspended solids concentrations less 
than $10 \mathrm{mg} \mathrm{l}^{-1}$ (Table 1), but how high can these concentrations and rates go before reefs and reef organisms are adversely affected? Do responses to terrigenous sediments differ from responses to calcium carbonate sediments? There is a need to study the effects of both reef-derived and anthropogenic sediments on different coral species and different reef organisms under as realistic conditions as possible. We need more field studies on responses of organisms to sediments during dredging and to application of sediments actually collected from construction and dredging sites.

Are short-term, acute pulses of sediments into the reef environment less detrimental than chronic sedimentation at lower levels? At what concentration of suspended sediments does coral growth cease? Does coral reef zonation shift to shallower depths with high turbidity? Only with greater understanding of coral physiology can we begin to differentiate the effects of disturbance, whether natural or man-made, from normal long-term fluctuations on reefs (Brown \& Howard 1985). What are the cumulative effects of a number of small development projects, and how do they compare to the effects from a single large project? We need answers to all of these questions to enable us to predict the consequences of coastal development projects. Computer models should be useful in this regard. Further attempts should be made to develop and refine realistic systems models of the interactions among mangroves, coral reefs, and seagrass beds (see Berwick \& Chamberlin 1985) and the effects of development on these interactions. Models of physical processes (e.g. sediment transport) must be complemented with better understanding of organism and ecosystem responses to sediment stress. We should be able to predict the response of a reef to a particular activity given information on the amount of sediment which will be introduced into the reef environment, the coral community composition, the depth of the reef, the percent coral cover, and the current patterns. Research should be designed to provide a basis for predicting the response of coral ecosystems to known inputs of sediments into reef waters from coastal development.

Acknowledgements. Special thanks to D. Hubbard, P. Edmunds, B. Brown, W. Jaap and J. Maragos for constructive criticism of this manuscript. Thanks also to L. McLain for help with the tables and figs.

\section{LITERATURE CITED}

Abdel-Salam, H. A., Porter, J. W. (1988). Physiological effects of sediment rejection on photosynthesis and respiration in three Caribbean reef corals. Proc. 6th int. Coral Reef Symp. 2: 285-292

Adey, W. H., Macintyre, I. C., Stuckenrath, R. (1977). Relict barrier reef system off St. Croix: its implications with respect to late Cenozoic coral reef development in the western Atlantic. Proc. 3rd int. Coral Reef Symp. 2: 15-21

Amesbury, S. S. (1981). Effects of turbidity on shallow water reef fish assemblages in Truk, Eastern Caroline Islands. Proc. 4th int. Coral Reef Congr. 6: 491-496

Amesbury, S. S., Clayshutte, R. N., Determan, T A., Hedlund, S. E., Eads, J. R. (1978). Environmental monitoring study of airport runway expansion site, Moen, Truk, Eastern Caroline Islands, Part A: Baseline study. Univ. of Guam Mar. Lab. Tech. Rep. No. 51, p. 1-87

Bak, R. P. M. (1978). Lethal and sublethal effects of dredging on reef corals. Mar. Pollut. Bull. 9: 14-16

Bak, R. P. M., Elgershuizen, J. H. B. W. (1976). Patterns of oil sediment rejection in corals. Mar. Biol. 37: 715-730

Bak, R. P. M., Engel, M. S. (1979). Distribution, abundance, and survival of juvenile hermatypic corals (Scleractinia) and the importance of life history strategies in parent coral community. Mar. Biol. 54: 341-352

Banner, A. H. (1968). A freshwater 'kill' on the coral reefs of Hawaii. Hawaii Inst. Mar. Biol. Tech. Rep. No. 15, p. 1-29

Barnes, D. J. (1973). Growth in colonial scleractinians. Bull. mar. Sci. 23: 280-298

Barnes, D. J., Crossland, C. J. (1982). Variability in the calcification rate of Acropora acuminata measured with radioisotopes. Coral Reefs 1: 53-57

Bell, J. D., Galzin, R. (1984). Influence of live coral cover on coral reef fish communities. Mar. Ecol. Prog. Ser. 15: 265-274

Berwick, N. L., Chamberlin, R. (1985). Systems analysis for integrating tropical coastal resources with watershed use. Proc. 5th int. Coral Reef Congr. 5: 569-575

Birkeland, C. (1977). The importance of rate of biomass accumulation in early successional stages of benthic communities to the survival of coral recruits. Proc. 3rd int. Coral Reef Congr. 1: 15-21

Birkeland, C., Rowley, D., Randall, R. H. (1981). Coral recruitment patterns at Guam. Proc. 4th int. Coral Reef Congr. 2 339-344

Blair, S. M., Flynn, B. S. (1988). Sunny Isles Beach Restoration Project: mechanical damage to the reefs adjacent to the borrow area. Metropolitan Dade County Department of Environmental Resources Management Tech. Rep. 88-14, p. $1-33$

Boulon, R. (1987). Basis for long-term monitoring of fish and shellfish species in the Virgin Islands National Park. Biosphere reserve research report no. 22. Virgin Islands Resource Management Cooperative/National Park Service, p. 1-66

Brock, V E., Van Heukelem, W., Helfrich, P. (1966). An ecological reconaissance of Johnston Island and the effects of dredging. Hawaii Inst. Mar. Biol. Tech. Rep. No. 11, p. 1-56

Brown, B. E., Howard, L. S. (1985). Assessing the effects of 'stress' on reef corals. Adv. mar. Biol. 22: 1-63

Brown, B. E., Howard, L. S., Le Tissier, M. D. (1986). Variation in the dominance and population structure of intertidal corals around Ko Phuket, Thailand. Res. Bull. Phuket mar. Biol. Cent. 41, p. 1-9

Chalker, B. E. (1981). Simulating light-saturation curves for photosynthesis and calcification by reef-building corals. Mar. Biol. 63: 135-141

Chansang, H., Boonyanate, P., Charuchinda, M. (1981). Effect of sedimentation from coastal mining on coral reefs on the northwestern coast of Phuket Island, Thailand. Proc. 4th int. Coral Reef. Symp. 1: 129-136

Chapell, J. (1980). Coral morphology, diversity and reef growth. Nature, Lond. 286: 249-252

Chapman, G. A. (1979). Honolulu International Airport Reef 
runway post-construction environmental impact report Parsons, Hawaii, Honolulu

Cintron, G., McKenzie, F., Olazagasti, R. (1974). Studies at the PRINUL site. Final Report Missions 3 and 5. PRINUL, San German, Puerto Rico, p. 1-27

Cortes, J., Risk, M. J. (1984). El arrecife coralino del Parque Nacional Cahuita, Costa Rica. Revta Biol. trop. 32: 109-121

Dahi, A. L. (1985). Status and conservation of South Pacific coral reefs. Proc. 5th int. Coral Reef Congr. 6: 509-513

Dallmeyer, D. G., Porter, J. W., Smith, G. J. (1982). Effects of particulate peat on the behavior and physiology of the Jamaican reef-building coral Montastrea annularis. Mar Biol. 68: 229-233

Dodge, R. E. (1982). Effects of drilling mud on the reef-building coral Montastrea annularis. Mar. Biol. 71: 141-147

Dodge, R. E., Aller, R. C., Thompson, J. (1974). Coral growth related to resuspension of bottom sediments. Nature, Lond. 247: 574-577

Dodge, R. E., Brass, G. W. (1984). Skeletal extension, density and calcification of the reef coral, Montastrea annularis: St. Croix, U.S. Virgin Islands. Bull. mar. Sci. 34: 288-307

Dodge, R. E., Lang, J. (1983). Environmental correlates of hermatypic coral (Montastrea annularis) growth on the east Flower Garden Bank, Northwest Gulf of Mexico. Limnol. Oceanogr. 28: 228-240

Dodge, R. E., Szmant-Froelich, A. (1985). Effects of drilling fluids on reef corals: a review. In: Duedall, I. W., Kester, D R., Park, P. K., Ketchum, B. H. (eds.) Wastes in the ocean, Vol. 4. Wiley (Interscience), New York, p. 341-364

Dodge, R. E., Vaisnys, J. R. (1977). Coral populations and growth patterns: responses to sedimentation and turbidity associated with dredging. J. mar. Res. 35: 715-730

Dollar, S. J., Grigg, R. W. (1981). Impact of a kaolin clay spill on a coral reef in Hawaii. Mar. Biol. 65: 269-276

DuBois, R., Towle, E. (1985). Coral harvesting and sand mining management practices. In: Clark, J. (ed.) Coastal resources management: development case studies. Coastal Publication No. 3. Research Planning Institute, Columbia, SC, p. 203-289

Dustan, P. (1975). Growth and form in the reef-building coral Montastrea annularis. Mar. Biol. 33: 101-107

Edmondson, C. H. (1929). Growth of Hawaiian corals. Bull Bernice P. Bishop Mus. 58: 1-38

Edmunds, P. J., Davies, P. S. (1986). An energy budget for Porites porites (Scleractinia). Mar. Biol. 92: 339-347

Edmunds, P. J., Davies, P. S. (1989). An energy budget for Porites porites (Scleractinia) growing in a stressed environment. Coral Reefs 8: $37-43$

Endean, R. (1976). Destruction and recovery of coral reef communities. In: Jones, O. A., Endean, R. (eds.) Biology and geology of coral reefs, vol.3. Biology 2. Academic Press, New York p. 215-254

Foster, A. B. (1979). Phenotypic plasticity in the reef corals Montastrea annularis (Ellis \& Solander) and Siderastrea siderea (Ellis and Solander). J. exp. mar Biol. Ecol. 39 25-54

Foster, A. B. (1980). Environmental variation in skeletal morphology within the Caribbean reef corals Montastrea annularis and Siderastrea siderea. Bull. mar. Sci. 30 $678-709$

Galzin, R. (1981). Effects of coral sand dredging on fish fauna in the lagoon of the Grand Cul de Sac Marine, GuadalupeFrench West Indies. Proc. 4 th int. Coral Reef Congr. 1. 115-121

Gladfelter, E. H. (1982). Skeletal development in Acropora cervicornis: I. Patterns of calcium carbonate accretion in the axial corallite. Coral Reefs 1. 45-51
Gladfelter, E. H. (1983). Skeletal development in Acropora cervicomis: II. Diel patterns of calcium carbonate accretion. Coral Reefs 2: 91-100

Gladfelter, W. B., Ogden, J. C., Gladfelter, E. H. (1980). Similarity and diversity among coral reef fish communities: a comparison between tropical western Atlantic (Virgin Islands) and tropical Central Pacific (Marshall Islands) patch reefs. Ecology 61: 1156-1168

Goreau, T. F. (1964). Mass expulsion of zooxanthellae from Jamaican reef communities after Hurricane Flora. Science 145: $383-386$

Griffin, G. (1974). Case history of a typical dredge-fill project in the northern Florida Keys-effects on water clarity, sedimentation rates and biota. Publ. 33, Harbor Branch Foundation. Florida, p. 1-67

Grigg. D. I., Crean, R. F., van Eepoel, R. P. (1972). Marine environment of Brewer's Bay, St Thomas, V.I. with a summary of recent changes. Caribb. Res. Inst. Water Pollution Report. Rep. 15, p. 1-40

Hedley, C. (1925). The natural destruction of a coral reef. Report of Great Barrier Committee. Trans. R. Geogr. Soc. Australasia, Queensland 1: 35-40

Herrnkind, W. F., ButJer, IV, M. J., Tankersley, R. A. (1988). The effects of siltation on recruitment of spiny lobsters, Panulirus argus. Fish. Bull. U.S. 86: 331-338

Hixon, M. (1986). Fish predation and local prey diversity. In: Simenstad, C., Cailliet, G. (eds.) Contemporary studies on fish feeding. ISBN 90-6193, Dr W. Junk Publishers, Dordrecht, p. 235-257

Hodgson, G. Dixon, J. A. (1988). Logging versus fisheries and tourism in Palawan. Occasional papers of the East-West Environment and Policy Institute, Honolulu. Paper no. 7 p. 1-95

Hourigan, T. F., Tricas, T. B., Reese, E. S. (in press). Coral reef fishes as indicators of environmental stress in coral reefs. In: Marine organisms as indicators. Springer Verlag, New York

Hubbard, D. K. (1986). Sedimentation as a contral of reef development: St. Croix, U.S.V.I. Coral Reefs 5: 117-125

Hubbard, D. K. (1987). A general review of sedimentation as it relates to environmental stress in the Virgin Islands Biosphere Reserve and the Eastern Caribbean in general. Biosphere reserve research report no. 20. Virgin Islands Resource Management Cooperative/National Park Service, p. $1-41$

Hubbard, D. K., Burke, R. B., Gill, I. P. (1986). Styles of reef accretion along a steep, shelf-edge reef, St Croix, U.S. Virgin Islands. J. sedim. Petrol. 56: 848-861

Hubbard, D. K., Scaturo, D. (1985). Growth rates of seven species of scleractinian corals from Cane Bay and Salt River, St Croix, USVI. Bull. mar. Sci. 36: 325-338

Hubbard, D. K., Stump, J. D., Carter, B. (1987). Sedimentation and reef development in Hawksnest, Fish and Reef Bays, St John, U.S. Virgin Islands. Biosphere reserve research report 21. Virgin Islands Resource Management Cooperative/National Park Service, p. 1-99

Hubbard, J. A. E. B., Pocock, Y. B. (1972). Sediment rejection by recent scleractinian corals: a key to palaeo-environmental reconstruction. Geol. Rdsch. 61. 598-626

Hudson, J. H. (1981). Growth rates in Montastrea annularis: a record of environmental change in Key Largo Coral Reef Marine Sanctuary, Florida. Bull. mar Sci. 31: 444-459

Hudson, J. H., Shinn, E. A., Robbin, D. M. (1982). Effects of offshore oil drilling on Philippine reef corals. Bull. mar. Sci. 32: 890-908

Hughes, T., Jackson, J. (1985). Population dynamics and life histories of foliaceous corals. Ecol. Monogr. 55: 141-166 
Isdale, P. (1984). Fluorescent bands in massive corals record centuries of coastal rainfall. Nature, Lond. 310: 578-579

Jaap, W. C. (1984). The ecology of the south Florida coral reefs: a community profile. U.S. Fish Wildl. Service. FWS/ OBS-82/08. p. $1-138$

Jerlov, N. G. (1970). Light. In: Kinne, O. (ed.) Marine ecology, Vol. 1. Wiley Interscience, New York, p. 95-102

Johannes, R. E. (1975). Pollution and degradation of coral reef communities. In: Wood, E. J. F., Johannes, R. E. (eds.) Tropical marine pollution. Elsevier Scientific Publishing Company, Oxford, p. 1-181

Krone, M. A., Biggs, D. C. (1980). Sublethal metabolic responses of the hermatypic coral Madracis decactis exposed to drilling mud enriched with ferrochrome lignosulfate. In: Research on environmental fate and effects of drilling fluids and cuttings, Vol.2. Courtesy Associates, Washington, D.C., p. 1079-1100

Lasker, H. R. (1980). Sediment rejection by reef corals: the roles of behavior and morphology in Montastrea cavernosa (Linnaeus). J. exp. mar. Biol. Ecol. 47: 77-87

Logan, A. (1988). Sediment-shifting capability in the recent solitary coral Scolymia cubensis (Milne-Edwards and Haime) from Bermuda. Bull. mar. Sci. 43: 241-248

Loya, Y. (1976). Effects of water turbidity and sedimentation on the community structure of Puerto Rican reefs. Bull. mar. Sci. 26: 450-466

Luckhurst, B. E., Luckhurst, K. (1978). Analysis of the influence of substrate variables on coral reef fish communities. Mar. Biol. 49: 317-323

Macintyre, I. (1988). Modern coral reefs of western Atlantic: New geological perspective. Bull. Am. Ass. Petrol. Geol. 72: $1360-1369$

Maragos, J. E. (1972). A study of the ecology of Hawaiian reef corals. Ph. D. dissertation, Univ. of Hawaii, Honolulu

Maragos, J. E. (1974). Reef corals of Fanning Island. Pacif. Sci. 28: $247-255$

Maragos, J. E. (1983). Trip report - field inspection of Okat airfield and dock project site, 1-2 March 1983, Kosrae State, Trust Territory of the Pacific Islands (TTPI). U.S. Army Engineer Division, Pacific Ocean, Honolulu (PODED-PV), p. 1-10

Maragos, J. E. (1984). Trip report - Kosrae airfield and dock project at Okat. (TTPI) and followup meeting with Navy OICC, Guam. U.S. Army Engineer Division, Pacific Ocean, Honolulu (PODED-PV), p. 1--6

Maragos, J. E., Evans, C., Holthus, P. J. (1985). Reef corals in Kaneohe Bay six years before and after termination of sewage discharges. Proc. 5th int. Coral Reef Congr. 4: 189-194

Marsh, J. A. Jr, Gordon, G. D. (1974). Marine environmental effects of dredging and power plant construction. Univ. of Guam Mar. Lab. Tech. Rep. 8, p. 1-56

Marshall, S. M., Orr, A. P. (1931). Sedimentation on Low Isles Reef and its relation to coral growth. Scient. Rep. Gt Barrier Reef Exped. 1: 94-133

Marszalek, D. S. (1981). Impact of dredging on a subtropical reef community, Southeast Florida, U.S.A. Proc. 4th int. Coral Reef Congr. 1: 147-153

Mayer, A. G. (1918). Ecology of the Murray Island coral reef. Publs Carnegie Inst. 183, p. 1-24

Meyer, J., Schultz, E., Helfman, G. (1983). Fish schools: an asset to corals. Science 220: 1047-1049

Morelock, J., Grove, K., Hernandez, M. (1983). Oceanography and patterns of shelf sediments, Mayaguez, Puerto Rico. J. sedim. Petrol. 53: 371-381

Nichols, M., Brush, G. (1988). Man's long-term impact on sedimentation: evidence from salt pond deposits. Bio- sphere reserve research report no. 23. Virgin Islands Resource Management Cooperative/National Park Service. p. $1-26$

Odum, H. T. (1967). Work circuits and system stress. In: Young, H. E. (ed.) Symposium on primary productivity and mineral cycling in natural ecosystems. Univ. of Maine Press, Orono, p. 81-138

Ogden, J., Ehrlich, P. (1977). The behavior of heterotypic resting schools of juvenile grunts (Pomadasyidae). Mar. Biol. 42: 273-280

Ogden, J., Lobel, P. (1978). The role of herbivorous fishes and urchins in coral reef communities. Environ. Biol. Fish. 3: $49-63$

Ott, B. (1975). Community patterns on a submerged barrier reef at Barbados, West Indies. Int. Revue ges. Hydrobiol. 60: 719-736

Pastorok, R. A., Bilyard, G. R. (1985). Effects of sewage pollution on coral-reef communities. Mar. Ecol. Prog. Ser. 21: $175-189$

Penn, N. (1981). The environmental consequences and management of coral sand dredging from seagrass beds in the Suva region, Fiji Islands. Bull. mar. Sci. 31: 814

Peters, E. C., Pilson, M. E. Q. (1985). A comparative study of the effects of sedimentation on symbiotic and asymbiotic colonies of the coral Astrangia danae Milne Edwards and Haime 1849. J. exp. mar. Biol. Ecol. 92: 215-230

Porter. J. W. (1972), Patterns of species diversity in Caribbean reef corals. Ecology 53: 745--748

Porter, J. W. (1976). Autotrophy, heterotrophy, and resource partitioning in Caribbean reef-building corals. Am. Nat. 110: $737-742$

Randall, J. (1974). The effect of fistes on coral reefs. Proc. 2nd int. Coral Reef Symp. I: 159-166

Randall, R. H., Birkeland, C. (1978). Guam's reefs and beaches. Part II. Sedimentation studies at Fouha Bay and Ylig Bay. Univ. of Guam Mar. Lab. Tech. Rep. 47, p. 1-77

Risk, M. J. (1972). Fish diversity on a coral reef in the Virgin Islands. Atoll Res. Bull. 153, p. 1-6

Rogers, C. S. (1979). The effect of shading on coral reef structure and function. J. exp. mar. Biol. Ecol. 41: 269-288

Rogers, C. S. (1982). The marine environments of Brewers Bay, Perseverance Bay, Flat Cay and Saba Island, St. Thomas, U.S.V.I., with emphasis on coral reefs and seagrass beds. (November 1978-July 1981). Dept. of Conservation and Cultural Affairs, Gov't of the Virgin Islands, p. $1-181$

Rogers, C. S. (1983). Sublethal and lethal effects of sediments applied to common Caribbean reef corals in the field. Mar. Pollut. Bull. 14: 378-382

Rogers, C. S. (1985). Degradation of Caribbean and Western Atlantic coral reefs and decline of associated fisheries. Proc. 5th int. Coral Reef Congr 6: 491-496

Rogers, C. S., Fitz, H. C., Gilnack, M., Beets, J., Hardin, J. (1984). Scleractinian coral recruitment patterns at Salt River Submarine Canyon. St. Croix, U.S.V.I. Coral Reefs 3: 69-76

Roy, K. J. (1970). Changes in bathymetric configuration, Kaneohe Bay, Oahu, 1882-1969. Rep. Hawaii Inst. Geophysics, 70-15, p. 1-26

Roy, K. J., Smith, S. V. (1971). Sedimentation and coral reef development in turbid water: Fanning Lagoon. Pacif. Sci. 25: $234-248$

Salvat, B. (1987). Dredging in coral reefs. In: Salvat, B. (ed.) Human impacts on coral reefs: facts and recommendations. Antenne Museum EPHE, Moorea, French Polynesia, p. $165-184$

Sano, M., Shimizu, M., Nose, Y. (1987). Long term effects of 
destruction of hermatypic corals by Acanthaster planci infestation on reef fish communities at Iriomote Island, Japan. Mar. Ecol. Prog. Ser. 37: 191-199

Sheppard, C. R. C. (1980). Coral fauna of Diego Garcia lagoon, following harbor construction. Mar. Pollut. Bull. 11: $227-230$

Sheppard, C. R. C. (1982). Coral populations on reef slopes and their major controls. Mar. Ecol. Prog. Ser. 7: 83-115

Szmant-Froelich, A., Johnson, V., Hoehn, T., Battey, J., Smith, G. J., Fleischman, E., Porter, J., Dallmeyer, D. (1981). The physiological effects of oil drilling muds on the Caribbean coral Montastrea annularis. Proc. 4 th int. Coral Reef Symp. 1: $163-168$

Thayer, S. W., Colby, D. R., Hettler, W. F. Jr (1987). Utilization of the red mangrove prop root habitat by fishes in South Florida. Mar. Ecol. Prog. Ser. 35: 25-38

Thompson, J. H. Jr (1979). Effects of drilling mud on seven species of reef building corals as measured in field and laboratory. Texas A \& M University, College Station, U.S.G.S. Rep., p. 1-29

Thompson, J. H. Jr (1980). Responses of selected scleractinian corals to drilling fluids used in the marine environment. Ph. D. dissertation, Texas A \& M University, College Station

This review was presented by Professor C. Birkeland, Guam, USA
Thompson, J. H. Jr, Bright, T. J. (1977). Effects of drill mud on sediment clearing rate of certain hermatypic corals. Am. Petr. Institute, Washintgon, D.C., Publ. no. 4284 p. $495-498$

Thompson, J. H., Bright, T J. (1980). Effects of an offshore drilling fluid on selected corals. In: Research on environmental fate and effects of drilling fluids and cuttings 2 Courtesy Associates, Washington, D.C., p. 1044-1078

Tomascik, T., Sander, F. (1985). Effects of eutrophication on reef-building corals. II. Structure of scleractinian coral communities on fringing reefs, Barbados, West Indies. Mar. Biol. 94: 53-75

Tomascik, T., Sander, F. (1987). Effects of eutrophication on reef-building corals. III. Reproduction of the reef-building coral Porites porites. Mar. Biol. 94: 77-94

U.S. Army Corps of Engineers, Honolulu District (1983). A decade of ecological studies following construction of Honokohau Small Boat Harbor, Kona, Hawaii, p. 1-92

Voss, G. L. (1988). Coral reefs of Florida. Pineapple Press Inc., Sarasota, Florida

White, A. T. (1987). Effects of construction activity on coral reef and lagoon systems. In: Salvat, B. (ed.) Human impacts on coral reefs: facts and recommendations. Antenne Museum EPHE, Moorea, French Polynesia p. 185-194

Manuscript first received: May 15, 1989

Revised version accepted: January 8, 1990 